\title{
12. PETROLOGY AND CHEMISTRY OF BASALTS FROM THE NAZCA PLATE: PART 2-MAJOR AND TRACE ELEMENT CHEMISTRY
}

\author{
J.M. Rhodes, ${ }^{1}$ D.P. Blanchard, ${ }^{2}$ K. V. Rodgers, ${ }^{1}$ J.W. Jacobs, ${ }^{1}$ and J.C. Brannon ${ }^{1}$
}

\section{INTRODUCTION}

In this report we discuss the chemical aspects of a combined geochemical and petrological study of 22 basalt samples selected from drill cores during Leg 34 of the Deep Sea Drilling Project. A companion paper by Donaldson et al. (this volume) reports on the petrographic aspects of this study.

The samples are from Holes 319, 319A, 320B, and 321 , all located on the Nazca plate, where basaltic basement rocks ranging in age from 15 to 45 m.y. were cored (Hart et al., 1974). Figure 1 shows the location of each sample within the drill core, with respect to the lithological and cooling units identified aboard Glomar Challenger.

Major, minor, and trace element analyses of basalts from Holes 319 and 319A are given in Table 1; those from Holes 320B and 321 are given in Table 2. Major element data were obtained by $\mathrm{X}$-ray fluorescence analysis (XRF) on fused glass discs prepared by fusing the sample with a lanthanum-bearing lithium borate fusion mixture (Norrish and Hutton, 1969). FeO was measured titrimetrically using the modified cold acid digestion method of Wilson (Maxwell, 1968), and $\mathrm{Fe}_{2} \mathrm{O}_{3}$ was obtained by difference from the XRF determination of total iron. $\mathrm{H}_{2} \mathrm{O}$ values were obtained gravimetrically, and $\mathrm{CO}_{2}$ was calculated from total carbon measurements using the gas chromatographic method of Moore et al. (1970). Sodium and the trace elements $\mathrm{La}, \mathrm{Ce}, \mathrm{Sm}$, $\mathrm{Dy}, \mathrm{Tb}, \mathrm{Yb}, \mathrm{Lu}, \mathrm{Sc}, \mathrm{Hf}, \mathrm{Cr}$, Ta were determined by Instrumental Neutron Activation Analysis (INAA) following the methods of Haskin et al. (1973). The remaining trace elements $(\mathrm{Sr}, \mathrm{Rb}, \mathrm{Zr}, \mathrm{Nb}, \mathrm{Y}, \mathrm{Ni})$ were determined by XRF analysis on pressed powders, with corrections made for matrix effects by direct measurement of mass-absorption coefficients (Norrish and Chappell, 1967).

The USGS standard W-1 was analyzed concurrently with these samples (Table 2), providing an estimate of the accuracy and reliability of the analyses.

\section{BASALT CHEMISTRY}

The basalts from all three Leg 34 sites have many compositional features in common. All have the major, minor, and trace element characteristics typical of ocean ridge basalts and are compositionally distinct from alkaline basalts, transitional tholeiites, and oceanic island tholeiites. These characteristics are particularly well illustrated by the chondrite-normalized rare-earth

\footnotetext{
'Lockheed Electronics Corporation, Houston, Texas
}

${ }^{2}$ NASA Johnson Space Center, Houston, Texas. abundance patterns (Figure 2) and by abundances of "alteration resistant" discriminants such as $\mathrm{TiO}_{2}, \mathrm{P}_{2} \mathrm{O}_{5}$, $\mathrm{Zr}, \mathrm{Y}, \mathrm{Nb}$, and $\mathrm{Sr}$, all of which, with the exception of $\mathrm{Sr}$, are within the high part of the range encompassed by typical mid-ocean ridge tholeiites (Cann, 1970; Kay et al., 1974).

Alteration, as evidenced by total water and $\mathrm{CO}_{2}$ contents and by the ratio of ferric to total iron, is more extensive than was indicated by the preliminary sample descriptions (Hart et al., 1974), but nevertheless is low for DSDP basalt samples. Some samples, particularly those from Hole 320B and Site 321, contain more than $2 \%$ water, and several have high oxidation ratios $\left(\mathrm{Fe}_{2} \mathrm{O}_{3} /\left[\mathrm{Fe}_{2} \mathrm{O}_{3}+\mathrm{FeO}\right]\right)$. The sulfur contents of the fresher samples range from $0.10 \%$ to $0.17 \%$, typical values for basalts extruded in deep water (Moore and Fabbi, 1971); whereas the more altered samples have lost almost all their sulfur. Depletion in sulfur content thus provides another useful indicator of seawater alteration in submarine basalts. The alkali content (K, $\mathrm{Rb}$ ) is also typical of ocean ridge basalts. Though generally low, the alkalis vary widely, reflecting different degrees of seawater alteration. They are highest in concentration in those samples that are strongly oxidized and depleted in sulfur. These particular samples have much lower $\mathrm{K} / \mathrm{Rb}$ ratios than the less altered samples (Hart, 1971).

Figure 3 illustrates the normative plagioclase, olivine, and pyroxene contents of these basalts.All contain less than $10 \%$ normative olivine, and a few samples, mostly from Site 321, are slightly quartz normative. Most samples, from all three sites, plot close to or on the inferred plagioclase-olivine cotectic (Shido et al., 1971), suggesting that these two minerals are the liquidus phases. This observation is consistent with the observed phenocryst assemblage (Donaldson et al., this volume).

It is evident from Figure 3 that the Leg 34 basalts contain a high proportion of normative pyroxene and are of a cotectic, or near cotectic, nature, with respect to olivine, plagioclase, and pyroxene. These characteristics are consistent with the argument that the Leg 34 basalts are samples of basalts more evolved than many midocean ridge basalts. The evolved nature of these samples is further emphasized by their high iron, titanium, and refractory trace element concentrations $(\mathrm{Zr}, \mathrm{Y}, \mathrm{Hf}$, rareearths); the high normative and modal abundances of opaque phases; high normative albite content; and their unusually low $\mathrm{Mg} /(\mathrm{Mg}+\mathrm{Fe})$ values with correspondingly low $\mathrm{Ni}$ abundances. The fractionated nature of these samples, relative to more typical ocean ridge basalts, is illustrated by a plot of $\mathrm{TiO}_{2}$ content versus $\mathrm{Mg}$ / $(\mathrm{Mg}+\mathrm{Fe})$ ratios (Figure 4). Similar relationships are observed when other indicators of magmatic fractionation 


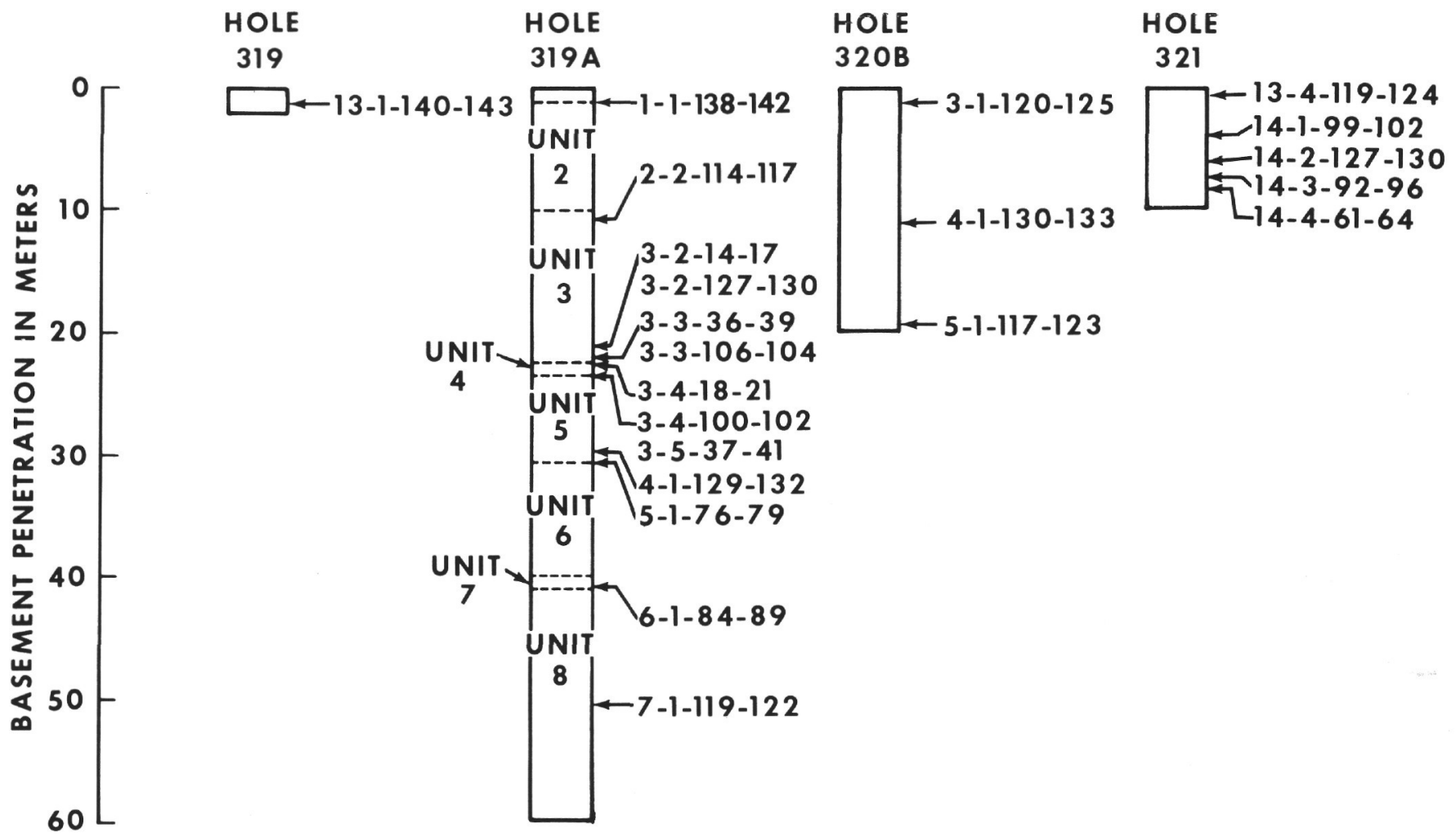

Figure 1. Location of samples studied in this report with respect to depth of basement penetration and position within designated cooling units.

such as normative albite/(albite + anorthite), or lithophile trace element abundances are plotted versus $\mathrm{Mg} /(\mathrm{Mg}+\mathrm{Fe})$.

The principal differences in basalt chemistry between the three sites are illustrated in Figure 4 and in the chondrite-normalized rare-earth abundances (Figure 2). Basalt from the uppermost flow unit of Hole 319A is closely similar in bulk composition to the basalt cored at the base of Hole 319 , and both probably belong to the same magmatic unit. They are the most "primitive" of the Leg 34 basalts, with $\mathrm{Mg} /(\mathrm{Mg}+\mathrm{Fe})$ values typical of ocean ridge tholeiites. Compared to other samples from Hole $319 \mathrm{~A}$ and the other Leg 34 basalts, they have the lowest total iron, $\mathrm{TiO}_{2}$ and lithophile trace element abundances, and show the greatest light rare-earth depletion, with $\mathrm{La} / \mathrm{Sm}$ ratios of about 0.6.

The remaining samples in Hole $319 \mathrm{~A}$, although taken from several flow units of varying thickness (Figure 1), are all compositionally similar, exhibiting little discernible variation within and between flow units. Compared to the overlying samples from Unit 1 , they are enriched in lithophile trace elements, particularly $\mathrm{Zr}$ and the light rare-earths, have higher $\mathrm{La} / \mathrm{Sm}$ ratios, and are more fractionated, with higher iron and titanium concentrations and correspondingly lower $\mathrm{Mg} /(\mathrm{Mg}+\mathrm{Fe})$ values. One sample in this group (319A-3-2, 127-130 cm) has an exceptionally low $\mathrm{Mg} /(\mathrm{Mg}+\mathrm{Fe})$ value of about 0.50 with no corresponding increase in $\mathrm{TiO}_{2}$ or lithophile trace element abundances. This is one of the most highly oxidized of the Leg 34 samples and may have lost magnesium due to extensive alteration (Matthews, 1971; Ridley et al., 1974).

We have analyzed three samples from Hole 320B -two from thin cooling units from the upper part of the core and one from a more massive unit at the bottom of the hole. They are chemically distinct, the upper samples having markedly higher $\mathrm{Ni}, \mathrm{Cr}$, and $\mathrm{Mg} /(\mathrm{Mg}+\mathrm{Fe})$, and lower concentrations of total iron, $\mathrm{TiO}_{2}, \mathrm{P}_{2} \mathrm{O}_{5}, \mathrm{Zr}$, $\mathrm{Y}, \mathrm{Nb}, \mathrm{Hf}, \mathrm{Sc}$, and rare-earth elements than the lower sample. The upper samples from Hole 320B have similar $\mathrm{Mg} /(\mathrm{Mg}+\mathrm{Fe})$ values to the majority of samples from Hole 319A, slightly higher $\mathrm{Sr}$ concentrations, and somewhat lower amounts of Sc and lithophile trace elements. The lowermost sample in Hole 320B has higher concentrations of the lithophile elements and markedly lower $\mathrm{Mg} /(\mathrm{Mg}+\mathrm{Fe})$ values than either the Hole 319 or higher Hole 320B samples. All Hole 320B samples are strongly oxidized and may have lost magnesium due to seawater alteration, thus giving anomalously low $\mathrm{Mg} /(\mathrm{Mg}+\mathrm{Fe})$ values. This suggestion gains support, particularly for the uppermost samples, from the unusually high $\mathrm{Cr}$ and $\mathrm{Ni}$ concentrations and low lithophile element abundances relative to their $\mathrm{Mg} /(\mathrm{Mg}+\mathrm{Fe})$ values.

Basalts from Site 321 are uniform in composition and are the most evolved of all of the Leg 34 basalts with respect to their normative mineralogy (Figure 3) and their trace element abundances. Most appear to be relatively unaltered, with low oxidation ratios and total water contents of less than $2 \%$. They have the lowest 
TABLE 1

Chemical Composition of Basalts From Site 319

\begin{tabular}{|c|c|c|c|c|c|c|c|c|c|c|c|c|c|c|}
\hline & \multicolumn{14}{|c|}{ Sample (Interval in cm) } \\
\hline & $\begin{array}{c}319- \\
13-1 \\
140-143\end{array}$ & $\begin{array}{c}319 \mathrm{~A} \\
1-1 \\
138-142\end{array}$ & $\begin{array}{c}319 A- \\
2-2 \\
114-117\end{array}$ & $\begin{array}{c}319 A- \\
3-2, \\
14-17\end{array}$ & $\begin{array}{c}319 \mathrm{~A}- \\
3-2 \\
127-130 \\
\end{array}$ & $\begin{array}{c}319 A- \\
3-3 \\
36-39\end{array}$ & $\begin{array}{c}319 A- \\
3-3, \\
106-109\end{array}$ & $\begin{array}{c}319 \mathrm{~A}- \\
3-4 \\
18-21\end{array}$ & $\begin{array}{c}\text { 319A- } \\
3-4, \\
100-102\end{array}$ & $\begin{array}{c}319 A- \\
3-5 \\
37-41\end{array}$ & $\begin{array}{c}319 \mathrm{~A}- \\
4-11 \\
129-132 \\
\end{array}$ & $\begin{array}{c}319 \mathrm{~A}- \\
5-1, \\
76-79\end{array}$ & $\begin{array}{c}319 \mathrm{~A}- \\
6-1, \\
84-89\end{array}$ & $\begin{array}{c}319 \mathrm{~A}- \\
7-1, \\
119-122 \\
\end{array}$ \\
\hline & (1) & (1) & (3) & (3) & (3) & (3) & (3) & (3) & (3) & (4) & (5) & (5) & (7) & $(8)$ \\
\hline \multicolumn{15}{|c|}{ Major Elements in \% (XRF) } \\
\hline $\mathrm{SiO}_{2}$ & 50.02 & 50.30 & 49.16 & 49.95 & 49.40 & 49.44 & 49.05 & 49.80 & 49.56 & 49.20 & 49.00 & 49.22 & 50.37 & 49.02 \\
\hline $\mathrm{TiO}_{2}$ & 1.17 & 1.18 & 1.98 & 2.06 & 1.91 & 1.99 & 1.96 & 1.95 & 1.93 & 1.91 & 1.90 & 1.81 & 1.93 & 1.75 \\
\hline $\mathrm{Al}_{2} \mathrm{O}_{3}$ & 14.79 & 15.01 & 14.06 & 14.11 & 14.13 & 14.55 & 14.32 & 14.20 & 14.20 & 14.11 & 13.95 & 13.98 & 14.90 & 14.08 \\
\hline $\mathrm{Fe}_{2} \mathrm{O}_{3}$ & 2.63 & 2.41 & 3.60 & 2.86 & 6.31 & 3.10 & 0.90 & 1.18 & 2.71 & 2.44 & 3.01 & 4.70 & 4.52 & 3.37 \\
\hline $\mathrm{FeO}$ & 6.79 & 6.70 & 7.45 & 8.24 & 5.72 & 7.26 & 9.84 & 9.79 & 8.56 & 8.75 & 8.21 & 6.54 & 5.44 & 7.55 \\
\hline $\mathrm{MnO}$ & 0.18 & 0.19 & 0.18 & 0.18 & 0.21 & 0.20 & 0.19 & 0.20 & 0.20 & 0.19 & 0.19 & 0.20 & 0.19 & 0.19 \\
\hline $\mathrm{MgO}$ & 7.58 & 7.44 & 6.66 & 6.61 & 5.76 & 6.89 & 6.66 & 6.74 & 7.11 & 7.18 & 7.22 & 7.22 & 5.55 & 7.21 \\
\hline $\mathrm{CaO}$ & 12.51 & 12.84 & 10.85 & 11.18 & 11.13 & 11.28 & 11.12 & 11.22 & 11.11 & 11.02 & 10.88 & 11.39 & 12.17 & 11.39 \\
\hline $\mathrm{Na}_{2} \mathrm{O}$ & 2.53 & 2.55 & 2.97 & 3.03 & 3.04 & 3.13 & 3.03 & 2.96 & 2.99 & 3.00 & 2.95 & 2.80 & 2.89 & 2.75 \\
\hline $\mathrm{K}_{2} \mathrm{O}$ & 0.09 & 0.15 & 0.11 & 0.11 & 0.66 & 0.13 & 0.11 & 0.12 & 0.11 & 0.11 & 0.11 & 0.12 & 0.45 & 0.16 \\
\hline $\mathrm{P}_{2} \mathrm{O}_{5}$ & 0.07 & 0.09 & 0.17 & 0.17 & 0.16 & 0.17 & 0.17 & 0.17 & 0.16 & 0.17 & 0.17 & 0.15 & 0.16 & 0.16 \\
\hline S & 0.10 & 0.03 & 0.13 & 0.14 & 0.00 & 0.13 & 0.13 & 0.13 & 0.13 & 0.17 & 0.13 & 0.13 & 0.03 & 0.13 \\
\hline $\mathrm{H}_{2} \mathrm{O}^{+}$ & 0.62 & 0.43 & 0.87 & 0.69 & 0.79 & 0.77 & 0.63 & 0.91 & 0.77 & 0.72 & 0.67 & 0.76 & 0.65 & 0.96 \\
\hline $\mathrm{H}_{2} \mathrm{O}^{-}$ & 0.74 & 0.47 & 1.20 & 0.63 & 0.86 & 0.65 & 1.04 & 0.61 & 0.47 & 0.56 & 1.04 & 0.97 & 0.82 & 0.96 \\
\hline $\mathrm{CO}_{2}$ & 0.49 & n.d. & 0.47 & 0.43 & 0.36 & 0.36 & 0.42 & 0.41 & 0.41 & 0.53 & 0.41 & 0.41 & 0.25 & 0.40 \\
\hline Total & 100.31 & 99.79 & 99.86 & 100.39 & 100.44 & 100.05 & 99.57 & 100.38 & 100.42 & 100.02 & 99.84 & 100.40 & 100.32 & 100.12 \\
\hline Total $\mathrm{Fe}$ as $\mathrm{FeO}$ & 9.16 & 8.87 & 10.69 & 10.81 & 11.40 & 10.05 & 10.65 & 10.85 & 11.00 & 10.95 & 10.91 & 10.77 & 9.51 & 10.58 \\
\hline $\mathrm{Fe}_{2} \mathrm{O}_{3}\left(\mathrm{Fe}_{2} \mathrm{O}_{3}+\mathrm{FeO}\right)$ & 0.287 & 0.272 & 0.337 & 0.265 & 0.553 & 0.309 & 0.085 & 0.109 & 0.246 & 0.223 & 0.276 & 0.436 & 0.475 & 0.319 \\
\hline $100 \mathrm{Mg}(\mathrm{Mg}+\mathrm{Fe})$ & 63.4 & 63.8 & 56.0 & 55.5 & 50.5 & 58.5 & 56.1 & 55.8 & 56.8 & 57.1 & 57.4 & 57.7 & 54.8 & 54.9 \\
\hline \multicolumn{15}{|c|}{ Trace Elements in ppm (XRF) } \\
\hline $\mathrm{Rb}$ & 1.5 & 3.2 & 0.7 & 0.7 & 17 & 1.0 & 0.5 & 0.9 & 0.5 & 0.7 & 0.4 & 1.5 & 8.9 & 1.5 \\
\hline $\mathrm{Sr}$ & 111 & 111 & 116 & 121 & 116 & 122 & 119 & 117 & 118 & 117 & 116 & 113 & 129 & 111 \\
\hline $\mathrm{Zr}$ & 67 & 67 & 135 & 139 & 127 & 135 & 131 & 126 & 129 & 131 & 128 & 118 & 127 & 115 \\
\hline $\mathrm{Nb}$ & 2.1 & 3.2 & 3.1 & 2.0 & 2.4 & 1.9 & 2.5 & 3.3 & 2.3 & 3.1 & 2.8 & 2.7 & 2.3 & 2.9 \\
\hline $\mathrm{Y}$ & 29 & 27 & 43 & 44 & 40 & 42 & 41 & 41 & 42 & 41 & 41 & 39 & 41 & 38 \\
\hline $\mathrm{Ni}$ & 105 & 107 & 81 & 75 & 66 & 161 & 94 & 87 & 91 & 95 & 101 & 85 & 101 & 92 \\
\hline \multicolumn{15}{|c|}{ Trace elements in ppm (INAA) } \\
\hline $\mathrm{La}$ & 1.57 & 1.47 & 4.44 & 4.16 & 4.22 & 3.85 & 3.70 & 3.83 & 3.61 & 3.70 & 3.65 & 3.19 & 3.55 & 3.31 \\
\hline $\mathrm{Ce}$ & 5.86 & 6.16 & 13.3 & 13.3 & 13.9 & 13.1 & 11.9 & 12.8 & 12.2 & 12.3 & 12.3 & 11.6 & 12.2 & 11.4 \\
\hline $\mathrm{Sm}$ & 2.40 & 2.59 & 4.77 & 4.72 & 4.56 & 4.36 & 4.31 & 4.34 & 4.19 & 4.14 & 4.25 & 4.16 & 4.17 & 3.90 \\
\hline $\mathrm{Eu}$ & 0.980 & 0.987 & 1.60 & 1.60 & 1.50 & 1.56 & 1.51 & 1.52 & 1.47 & 1.49 & 1.46 & 1.45 & 1.46 & 1.39 \\
\hline $\mathrm{Tb}$ & 0.713 & 0.804 & 1.28 & 1.07 & 1.17 & 0.971 & 0.924 & .97 & .93 & 1.10 & 1.07 & 0.90 & 0.92 & 0.931 \\
\hline $\mathrm{Yb}$ & 2.87 & 2.89 & 5.29 & 5.14 & 4.97 & 4.65 & 4.38 & 4.65 & 4.26 & 4.38 & 4.42 & 4.03 & 4.32 & 3.81 \\
\hline $\mathrm{Lu}$ & 0.451 & 0.512 & 0.805 & 0.782 & 0.747 & 0.712 & 0.673 & 0.776 & 0.678 & 0.679 & 0.661 & 0.688 & 0.677 & 0.637 \\
\hline Co & 89.0 & 151.0 & 83.3 & 58.1 & 61.2 & 69.3 & 60.8 & 78.6 & 59.6 & 63.8 & 64.4 & 78.1 & 74.0 & 60.0 \\
\hline Sc & 44.7 & 46.5 & 46.1 & 45.5 & 44.1 & 43.1 & 42.0 & 43.0 & 41.4 & 42.1 & 41.9 & 44.1 & 45.6 & 42.5 \\
\hline $\mathrm{Hf}$ & 1.83 & 1.94 & 3.8 & 3.77 & 3.5 & 3.77 & 3.72 & 3.86 & 3.48 & 3.45 & 3.48 & 3.2 & 3.16 & 3.20 \\
\hline $\mathrm{Cr}$ & 250 & 270 & 247 & 220 & 247 & 233 & 214 & 233 & 215 & 210 & 222 & 264 & 273 & 240 \\
\hline $\mathrm{Ta}$ & 2.6 & 5.5 & 2.7 & 1.2 & 2.1 & 1.1 & 1.9 & 4.0 & 2.0 & 2.1 & 2.0 & 2.6 & 1.3 & 1.3 \\
\hline
\end{tabular}


TABLE 2

Chemical Composition of Basalts from Sites 320 and 321

\begin{tabular}{|c|c|c|c|c|c|c|c|c|c|}
\hline & $\begin{array}{c}320 \mathrm{~B}- \\
3-1, \\
120-125\end{array}$ & $\begin{array}{c}320 \mathrm{~B}- \\
4-1, \\
130-133\end{array}$ & $\begin{array}{c}320 \mathrm{~B}- \\
5-1 \\
117-123\end{array}$ & $\begin{array}{c}321- \\
13-4 \\
119-124\end{array}$ & $\begin{array}{c}321- \\
14-1 \\
99-102\end{array}$ & $\begin{array}{c}321- \\
14-2 \\
127-130\end{array}$ & $\begin{array}{l}321- \\
14-3, \\
92-96\end{array}$ & $\begin{array}{l}321- \\
14-4, \\
61-64\end{array}$ & W-1 \\
\hline \multicolumn{10}{|c|}{ Major Elements in \% (XRF) } \\
\hline $\mathrm{SiO}_{2}$ & 48.43 & 49.59 & 49.89 & 48.19 & 49.29 & 49.53 & 48.24 & 49.52 & 52.46 \\
\hline $\mathrm{TiO}_{2}$ & 1.48 & 1.51 & 2.13 & 2.46 & 2.32 & 2.35 & 2.32 & 2.34 & 1.07 \\
\hline $\mathrm{Al}_{2} \mathrm{O}_{3}$ & 15.84 & 15.54 & 13.53 & 13.86 & 13.03 & 12.99 & 12.99 & 12.90 & 14.99 \\
\hline $\mathrm{Fe}_{2} \mathrm{O}_{3}$ & 5.07 & 7.60 & 6.39 & 6.55 & 2.93 & 3.60 & 3.52 & 3.79 & 1.23 \\
\hline $\mathrm{FeO}$ & 4.90 & 2.23 & 6.08 & 6.38 & 9.84 & 9.75 & 9.41 & 9.97 & 8.83 \\
\hline $\mathrm{MnO}$ & 0.17 & 0.16 & 0.21 & 0.21 & 0.25 & 0.20 & 0.22 & 0.21 & 0.19 \\
\hline $\mathrm{MgO}$ & 6.22 & 6.14 & 5.98 & 5.82 & 5.97 & 6.26 & 6.05 & 6.32 & 6.56 \\
\hline $\mathrm{CaO}$ & 11.86 & 11.79 & 10.09 & 10.61 & 10.65 & 9.59 & 10.95 & 9.80 & 10.97 \\
\hline $\mathrm{Na}_{2} \mathrm{O}$ & 2.85 & 3.05 & 3.00 & 2.65 & 2.65 & 2.71 & 2.69 & 2.75 & 2.25 \\
\hline $\mathrm{K}_{2} \mathrm{O}$ & 0.30 & 0.26 & 0.31 & 0.44 & 0.28 & 0.17 & 0.16 & 0.14 & 0.63 \\
\hline $\mathrm{P}_{2} \mathrm{O}_{5}$ & 0.14 & 0.13 & 0.19 & 0.25 & 0.23 & 0.21 & 0.22 & 0.22 & 0.13 \\
\hline $\mathrm{S}^{2}$ & 0.03 & 0.01 & 0.06 & 0.01 & 0.11 & 0.15 & 0.15 & 0.15 & 0.01 \\
\hline $\mathrm{H}_{2} \mathrm{O}^{+}$ & 1.20 & 1.02 & 0.79 & 0.95 & 0.72 & n.d. & 0.78 & 0.67 & 0.46 \\
\hline $\mathrm{H}_{2} \mathrm{O}^{-}$ & 1.39 & 1.59 & 1.08 & 1.70 & 0.99 & n.d. & 1.15 & 1.03 & 0.22 \\
\hline $\mathrm{CO}_{2}$ & 0.39 & n.d. & 0.22 & 0.13 & 0.36 & n.d. & 1.66 & 0.33 & n.d. \\
\hline Total & 100.27 & 100.62 & 99.95 & 100.21 & 99.62 & 97.51 & 100.51 & 100.14 & 100.00 \\
\hline Total $\mathrm{Fe}$ as $\mathrm{FeO}$ & 9.46 & 9.07 & 11.83 & 12.28 & 12.48 & 12.99 & 12.58 & 13.38 & 9.94 \\
\hline $\mathrm{Fe}_{2} \mathrm{O}_{3}\left(\mathrm{Fe}_{2} \mathrm{O}_{3}+\mathrm{FeO}\right)$ & 0.536 & 0.838 & 0.540 & 0.533 & 0.235 & 0.277 & 0.280 & 0.283 & 0.124 \\
\hline $100 \mathrm{Mg}(\mathrm{Mg}+\mathrm{Fe})$ & 57.7 & 58.6 & 50.4 & 48.7 & 49.9 & 48.9 & 49.0 & 48.3 & 57.7 \\
\hline \multicolumn{10}{|c|}{ Trace Elements in ppm (XRF) } \\
\hline $\mathrm{Rb}$ & 4.6 & 5.1 & 3.3 & 7.1 & 4.7 & 2.0 & 2.1 & 2.3 & 22 \\
\hline Sr & 128 & 126 & 135 & 105 & 103 & 96 & 105 & 97 & 192 \\
\hline $\mathrm{Zr}$ & 103 & 105 & 143 & 173 & 169 & 169 & 165 & 168 & 94 \\
\hline $\mathrm{Nb}$ & 1.5 & 2.6 & 3.3 & 5.5 & 5.9 & 5.9 & 5.7 & 5.7 & 7.0 \\
\hline Y & 33 & 33 & 47 & 57 & 57 & 52 & 55 & 54 & 21 \\
\hline $\mathrm{Ni}$ & 137 & 131 & 65 & 56 & 68 & 68 & 67 & 67 & 81 \\
\hline \multicolumn{10}{|c|}{ Trace Elements in ppm (INAA) } \\
\hline $\mathrm{La}$ & 3.24 & 3.35 & 4.29 & 5.92 & 5.22 & 5.48 & 5.91 & 5.55 & 11.1 \\
\hline $\mathrm{Ce}$ & 10.4 & 10.6 & 13.5 & 18.4 & 15.7 & 17.0 & 16.6 & 17.0 & 23.4 \\
\hline $\mathrm{Sm}$ & 3.52 & 3.47 & 5.14 & 5.58 & 4.91 & 5.12 & 5.36 & 5.21 & 3.23 \\
\hline $\mathrm{Eu}$ & 1.23 & 1.18 & 1.64 & 1.84 & 1.70 & 1.74 & 1.71 & 1.72 & 1.11 \\
\hline $\mathrm{Tb}$ & 0.860 & 0.85 & 1.2 & 1.3 & 1.2 & 1.22 & 1.20 & 1.24 & 0.623 \\
\hline $\mathrm{Yb}$ & 3.56 & 3.88 & 5.95 & 6.02 & 5.4 & 5.43 & 6.29 & 5.74 & 2.07 \\
\hline $\mathrm{Lu}$ & 0.543 & 0.584 & 0.899 & 0.905 & 0.822 & 0.834 & 0.956 & 0.861 & 0.333 \\
\hline $\mathrm{Co}$ & 59.2 & 56.0 & 58.9 & 53.4 & 75.8 & 51.4 & 58.0 & 52.3 & 47.0 \\
\hline $\mathrm{Sc}$ & 39.3 & 38.9 & 44.6 & 45.8 & 42.4 & 43.1 & 43.4 & 43.0 & 35.7 \\
\hline $\mathrm{Hf}$ & 2.82 & 2.69 & 3.93 & 4.46 & 4.83 & 4.39 & 4.20 & 4.18 & 2.52 \\
\hline $\mathrm{Cr}$ & 320 & 344 & 135 & 120 & 116 & 110 & 127 & 119 & 126 \\
\hline $\mathrm{Ta}$ & 1.1 & 0.77 & 0.94 & 0.95 & 1.4 & .88 & 1.2 & 1.1 & 0.55 \\
\hline
\end{tabular}

Note: n.d. = not determined.

$\mathrm{Mg} /(\mathrm{Mg}+\mathrm{Fe})$ values (about 0.5$), \mathrm{Ni}$ and $\mathrm{Cr}$ concentrations, and the highest $\mathrm{TiO}_{2}$, total $\mathrm{Fe}, \mathrm{P}_{2} \mathrm{O}_{5}, \mathrm{Zr}, \mathrm{Y}, \mathrm{Nb}$, $\mathrm{Hf}$, rare-earth concentrations, and $\mathrm{La} / \mathrm{Sm}$ ratios of all of the Leg 34 basalts. $\mathrm{Sr}$ is low (about $100 \mathrm{ppm}$ ) relative to the other Leg 34 samples.

\section{DISCUSSION}

The Leg 34 basalts exhibit the major, minor, and trace element characteristics of mid-ocean ridge basalts, and presumably were emplaced on the Galapagos Rise, a now-extinct spreading center (Herron, 1972).

The apparent cotectic nature of the Leg 34 basalts, in conjunction with their high lithophile element abun- dances and low $\mathrm{Mg} /(\mathrm{Mg}+\mathrm{Fe})$ values and $\mathrm{Ni}$ concentrations, precludes the possibility that they are primitive mantle melts. These are characteristics of evolved magmas, derived by crystal fractionation of more primitive parental liquids.

Despite the emphasis placed in the preceding section on the compositional variation both between and within sites, the Leg 34 basalts exhibit remarkably similar characteristics overall, particularly with respect to the lithophile element abundance patterns (Figure 2). Furthermore, there is a consistent and systematic variation in major, minor, and trace element chemistry from the high $\mathrm{Mg} /(\mathrm{Mg}+\mathrm{Fe})$ and low refractory trace element 


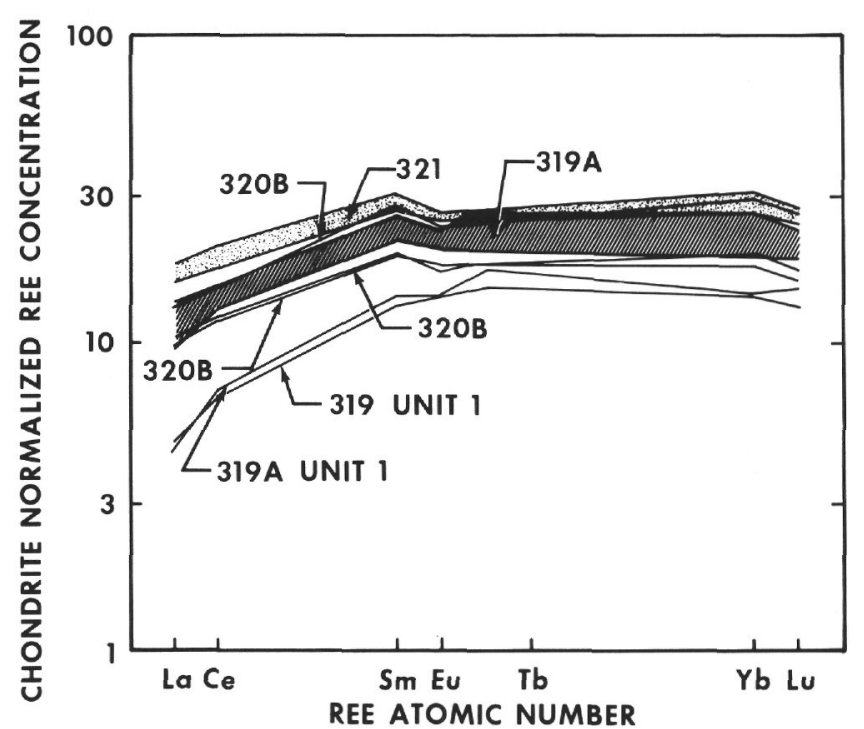

Figure 2. Chronite-normalized rare-earth abundances in DSDP Leg 34 basalts.

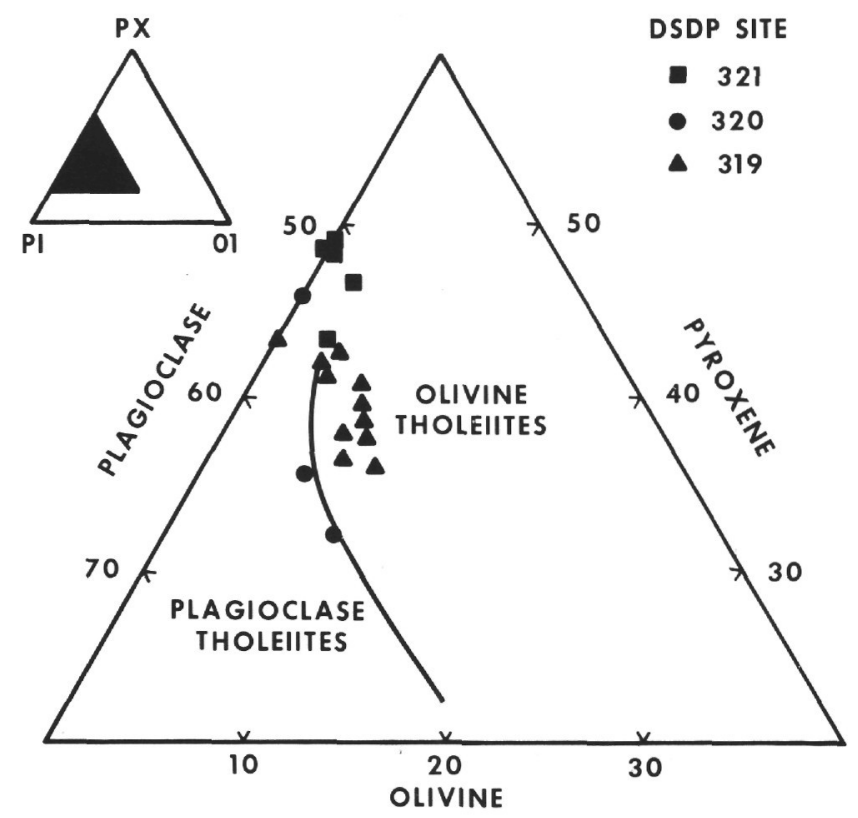

Figure 3. Normative olivine-plagioclase-pyroxene relationships in DSDP Leg 34 basalts. The classification and inferred olivine-plagioclase cotectic is from Shido et al., 1971.

samples from Unit 1 at Site 319 to the low $\mathrm{Mg}$ / $(\mathrm{Mg}+\mathrm{Fe})$ and high refractory element concentrations at Site 321. It is tempting, therefore, to ascribe these regular and systematic variations to progressive crystal fractionation from parental magmas of similar composition.

There are, however, problems with this interpretation. A more than twofold increase in $\mathrm{Zr}$, La, and $\mathrm{Ce}$ abundances between samples from Unit 1 of Hole 319 and those from the rest of the basalts at that site, requires extensive crystal fractionation with approximately $50 \%$ of the phenocryst phases removed. The differences between these and other lithophile element concentrations in

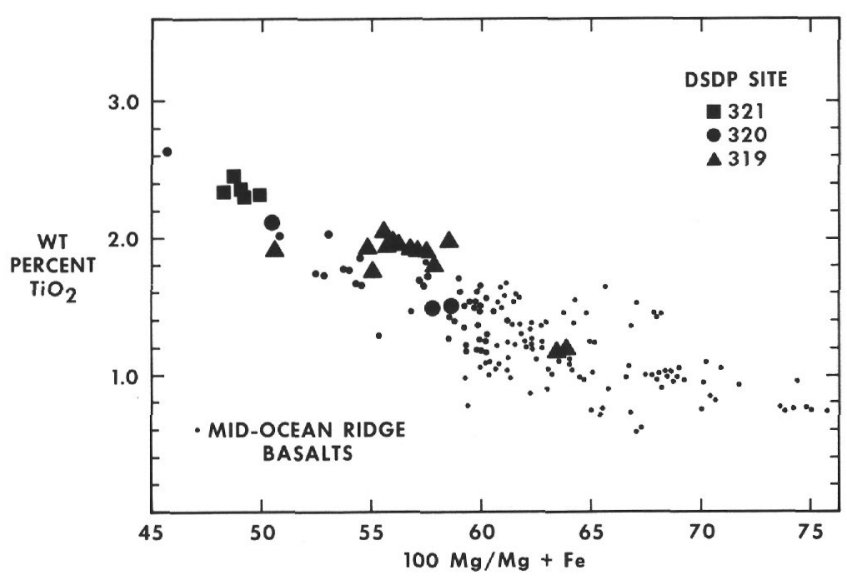

Figure 4. $\mathrm{TiO}_{2}$ versus $\mathrm{Mg} / \mathrm{Mg}+\mathrm{Fe}$ relationships in $\mathrm{DSDP}$ Leg 34 basalts. Data points for mid-ocean ridge basalts are from the literature and from unpublished analyses of the authors.

samples from Unit 1 of Hole 319 and samples from Site 321 are even larger, and require even greater amounts of fractionation. Such extensive fractionation is not compatible with the relatively small differences in major element chemistry, nor can it be readily modeled using the observed, and inferred, phenocryst assemblages of plagioclase and olivine (Donaldson et.al., this volume). Furthermore, we note that significant changes in $\mathrm{La} / \mathrm{Sm}$ ratios from about 0.60 in the samples from Unit 1 of Hole 319 , to about 0.88 for the rest of the Hole 319 samples, to 1.07 at Site 321, are not readily accomplishable by any reasonable near-surface fractionation process involving plagioclase, olivine, or pyroxene (Schilling, 1971) and must be attributed to differences in the source material.

Thus, we conclude that all of the Leg 34 basalts are evolved, having fractionated from more primitive parental compositions, with basalts from Site 321 having undergone a more extensive fractionation history than basalts from Sites 319 or 320 . The parental magmas for the rocks from all three sites were broadly similar, but distinct in detail and probably derived from somewhat different source materials.

\section{ACKNOWLEDGMENTS}

E.K. Gibson and G. Moore kindly provided us with unpublished total carbon data. Comments by C.H. Donaldson, A.M. Reid, and B.M. Jahn are appreciated.

\section{REFERENCES}

Cann, J.E., 1970. Rb, Sr, Y, $\mathrm{Zr}$ and $\mathrm{Nb}$ in some ocean floor basaltic rocks: Earth Planet. Sci. Lett., v. 10, p. 7-11.

Hart, S.R., 1971. K, Rb, Cs, Sr and Ba contents and $\mathrm{Sr}$ isotope ratios of ocean floor basalts: Phil. Trans. Roy. Soc. London, Sci. A, v. 268, p. 573-587.

Hart, S.R. et al., 1974. Leg 34 oceanic basalts and the Nazca Plate: Geotimes, v. 19, p. 20-24.

Haskin, L.A., Helmke, P.A., Blanchard, D.P., Jacobs, J.W., and Telander, K., 1973. Major and trace element abundances in samples from the lunar highlands: Geochim. Cosmochim. Acta, Suppl. 4, v. 2, p. 1275-1296. Pergamon. 
Herron, E. M., 1972. Sea floor spreading and Cenozoic history of the East-Central Pacific: Geol. Soc. Am. Bull., v. 83, p. 1671.

Kay, R., Hubbard, N.J., and Gast, P.W., 1970. Chemical characteristics and origin of oceanic ridge volcanic rocks: J. Geophys. Res., v. 75, p. 1585-1613.

Matthews, D.H., 1971. Altered basalts from Swallow Bank, an abyssal hill in the N.E. Atlantic, and from a nearby seamount: Phil. Trans. Roy. Soc. London, Ser. A, v. 268, p. 551-571.

Maxwell, J.A., 1968. Rock and mineral analysis: New York (Interscience), p. 419-421.

Moore, C.B., Gibson, E.K., Larimer, J.W., Lewis, C.F., and Nichiporuk, W., 1970. Total carbon and nitrogen abundances in Apollo 11 lunar samples and selected achondrites and basalts: Geochim. Cosmochim. Acta, Suppl. 1, v. 2, p. 1375-1382.
Moore, J.G., and Fabbi, B.P., 1971. An estimate of the juvenile sulfur content of basalt: Contrib. Mineral Petrol., v. 33, p. 118-127.

Norrish, K. and Chappell, B.W., 1967. X-ray fluorescence spectrography. In Zussman, J. (Ed.), Physical methods in determinative mineralogy: London (Academic Press).

Norrish, K. and Hutton, J.T., 1969. An accurate X-ray spectrographic method for the analysis of a wide range of geological samples: Geochim. Cosmochim. Acta, v. 33, p. 431-454.

Ridley, W.I., Rhodes, J.M., Reid, A.M., Jakes, P., Shih, C., and Bass, M.N. 1974. Basalts from Leg 6 of the Deep Sea Drilling Project: J. Petrol., v. 15, p. 140-159.

Schilling, J.G., 1971. Sea floor evolution: rare earth evidence: Phil. Trans. Roy. Soc. Lond., Ser. A, v. 268, p. 663-706.

Shido, F., Myashiro, A., and Ewing, M., 1971. Crystallization of abyssal tholeiites: Contrib. Mineral Petrol., v. 31, p. 251266. 